\title{
The Digitalization of Russian Politics and Political Participation
}

\author{
Mariëlle Wijermars
}

\subsection{INTRODUCTION}

Digitalization has affected politics in manifold ways, which result from the broad variety of technologies the term comprises. The Internet and, more recently, social media have, for instance, transformed political campaigning. The publication of public policy documents on government websites has created new expectations for political transparency. And, the introduction of voting computers and other e-voting solutions has made it possible to fundamentally rethink the voting process (e.g. online voting) while raising novel security concerns. In its strictest sense, digital politics can be defined as "how politicians employ the Internet to reach, court, and mobilize citizens and about how citizens rely on the web to inform themselves and engage with others politically" (Vaccari 2013, 4). Yet, as is pointed out by Stephen Coleman and Deen Freelon, "[ $\mathrm{t}] \mathrm{o}$ speak of digital politics is not simply to tell a story about how political routines are replicated online," rather it is about the (unforeseen) transformations of political practices that result from digitalization:

One feature of all technologies is that they are constitutive: they do not simply support predetermined courses of action, but open up new spaces of action, often contrary to the original intentions of inventors and sponsors. (Coleman and Freelon 2015, 1)

M. Wijermars $(\square)$

Maastricht University, Maastricht, The Netherlands e-mail: m.wijermars@maastrichtuniversity.nl 
In this chapter, I discuss the impact of digitalization on politics in Russia and the extent to which such unforeseen transformations in the political process have taken place. My discussion highlights four areas: political communication; political campaigning; voting; and, political participation and civic engagement.

While the digitalization of politics is a global trend, the characteristics and constraints of the national political context, such as the uptake speed of particular technologies, condition the shape digital politics takes. In the case of Russia, the proliferation of digital technologies unfolded in parallel with the "authoritarian turn" under President Vladimir Putin (Smyth 2016). As the examples discussed in this chapter will illustrate, digitalization has in fact been a deliberate politics on the part of the Russian state. While it is therefore necessary to consider to what extent the impact of digital technologies on politics unfolds differently in democracies as compared to hybrid regimes or nondemocracies, the opposite poles of the scholarly debate are similar: they either highlight the democratizing potential of digital tools or focus on their unintended or negative consequences. Given the different starting points-for example, the extent to which the object of study can be classified as a functioning democracy - this nonetheless results in different questions being asked.

Regarding Western liberal democracies, the democratizing potential is thought to lie in the opportunities digitalization provides for remedying the democratic deficit, for example through increased citizen participation, more direct communication channels between politicians and citizens through social media and the facilitation of forms of direct democracy. On the flipside, concerns have emerged about how online communications, in particular social media, may have polarizing effects that negatively affect societal stability and may be used to manipulate public opinion and election outcomes, as well as concerns about expanding state surveillance. In a similar vein, in the context of hybrid or non-democratic states, scholarly debate placed high hopes on the democratizing potential of the Internet. It was assumed that, among other factors, increased access to information online and the facilitation of political mobilization through the use of social media would empower citizens to challenge state power and demand a greater say in political decision-making (e.g. Castells 2012). Departing from the same assumption, many studies have examined states' efforts to control online communications and protect the political status quo in response (e.g. Deibert et al. 2010). The extent to which the Internet indeed functions as a "liberation technology" is increasingly questioned (e.g. Diamond 2010). Rather, it appears that the proliferation of Internet access has given rise to "networked authoritarianism" (MacKinnon 2011,33 ), a condition in which:

the single ruling party remains in control while a wide range of conversations about the country's problems nonetheless occurs on websites and socialnetworking services. The government follows this online chatter, and sometimes people are able to use the Internet to call attention to social problems or injustices and even manage to have an impact on government policies. As a result, the 
average person with Internet or mobile access has a much greater sense of freedom-and may feel that he has the ability to speak and be heard-in ways that were not possible under classic authoritarianism. At the same time, in the networked authoritarian state, there is no guarantee of individual rights and freedoms. (MacKinnon 2011, 33)

Notwithstanding the challenges that online communications raise for maintaining political control by increasing citizens' access to information and opportunities for free speech, it appears many authoritarian states are disinclined to (fully) limit access to the Internet. The seeming paradox-often referred to as the digital "dictator's dilemma"-may be explained by the potential economic consequences of such a decision, fear of popular unrest or the undermining a regime's democratic image or other sources of regime legitimacy. Yet, scholars have also noted that digitalization may, in fact, strengthen rather than weaken authoritarian regimes since the Internet can be used to effectuate political control, and information and opinions shared by citizens online can be a valuable resource to gauge public opinion on policy issues (e.g. Gunitsky 2015).

In this chapter, I first examine how the activities of political actors in Russia have changed as a result of digitalization, focusing on political communication and election campaigning, before turning my attention towards changes in voting and other forms of political participation. Many of these changes result from or developed against the backdrop of the introduction of open government ideas. Therefore, I open with an overview of actions in this domain. I argue that, while some of the changes described can be categorized as mere digital reproductions of existing political practices, several spheres of Russian politics have been transformed as a result of digitalization, in particular the opportunities for political opposition and civic engagement.

\subsection{Open Government}

The concept of open government promotes the ideal of transparency and accountability in governance: citizens should be able to access governmental documents and proceedings in order to establish an effective climate of checks and balances. In the past two decades, the concept has been inseparably intertwined with the notion of "e-government": the spread of Internet access and information technology (IT) infrastructures have made the Internet the perfect solution for achieving the aims of "open" government. Combined, the overall goals of open and e-government are to increase efficiency and transparency, as well as to simplify and improve the provision of governmental services to civilians and government-to-citizen communication. In Russia, the government initiated the expansion of information technologies, digitization, provision of online services, increased governmental transparency and so forth in earnest in 
the early 2000s (see also Chaps. 3 and 5 ). The Federal Program “Èlektronnấ Rossiâ (2002-2010)" (Electronic Russia)

called for the 'widespread integration' of information technology in government operations for such tasks as document management, registrations and declarations, and procurement tenders. To accomplish this mission, E-Russia's goals also included building up the nation's IT hardware and telecommunications infrastructure and developing a supportive legal and regulatory environment. Of note, the program's mission statement also called for 'significantly increasing the volume of information [that] government institutions provide to citizens, including via the Internet,' such as draft laws and decrees, government revenues, and budgets; performance reports by public enterprises; and assessments by auditing agencies. In the process, information technologies were seen as 'cardinally changing the basis of the government's relationship with citizens and businesses'. (Peterson 2005, 51)

While some government bodies were early adopters, from 2003 onwards all federal agencies were required to make a broad range of information accessible online, such as regulations and legislation, and information on the activities of their officials (Peterson 2005, 58).

With modernization and innovation as the buzzwords to define his "liberal" presidency, Dmitry Medvedev (2008-2012) launched a federal program aiming towards turning Russia into an "Information Society" (2011-2020) (Toepfl 2012, for more, see also Chap. 25) and a Minister of Open Government was appointed in 2012. In 2018, the ministerial position was discontinued, signaling the topic had lost priority with the authorities. The push towards open government has resulted in a significant increase in the availability of open government data. For example, information concerning government tenders can be accessed on the Goszakupki (Government procurement) portal, zakupki.gov.ru, while various open data sources are collected on the open data portal data.gov.ru. Through the creation of dedicated online platforms, the transparency of the legislative process has been enhanced; for example, the video recording of the Russian State Duma can be viewed on the platform video.duma.gov.ru and draft laws are made available for public discussion on the platform regulation.gov.ru (for more, see also Chap. 5). Yet, many issues remain, including a tendency to reintroduce restrictions on publicly available information. For example, in response to investigations by Alexei Navalny's FBK (Fond bor'by s korrupciej, Anti-Corruption Foundation), examples of which will be discussed below, the FSB (Federal'nấ služba bezopasnosti, Federal Security Service) proposed a law in 2015 that would severely restrict access to information about property ownership contained in Rosreestr (Federal Register). While the law was not passed, the Supreme Court determined in 2017 that Rosveestr is permitted to limit third-party access to ownership data, invoking the protection of personal data, thus setting a precedent (Kornia 2017). 


\subsection{Political Communication}

Parallel to the emphasis on adopting digital technologies in the policy sphere, significant changes were implemented in the authorities' communication strategies that, to an extent, resemble trends in political communication elsewhere. As a public advocate for technological innovation, Medvedev can be credited with pushing forward both the open government agenda and expanding Russian political communication from traditional media to online platforms. Through videos posted on the Kremlin website and, from 2009 onwards, his blog on LiveJournal (at the time the most popular blogging platform, see Podshibyakin 2010), Medvedev set an example for novel ways of communicating and engaging with citizens, and he pushed other government officials to start blogging as well (Gorham 2014). In 2010, some 35 per cent of Russian regional governors had a blog, a third of which emulated the videoblog format exemplified by the president (Toepfl 2012).

Medvedev's blogging activities were criticized for being "a blog without a blogger" (Yagodin 2012, 1422): his page featured videos posted by the presidential administration and functioned rather as a one-way channel for communication, lacking signs of Medvedev's direct contribution or his interaction with the online community, for example, with those commenting on his posts. Notwithstanding Medvedev's initial statements about aspiring towards a form of direct democracy through digital means, in practice most Russian politicians used their online communications "in ways that minimize the perils of truly direct online interaction and opting, instead, for a more hierarchical model of communication grounded in the discourse of 'e-government" (Gorham 2014, $235)$. Rather than entering into conversations with engaged citizens, the online communication strategies they chose opted for "the carefully structured, monitored, and filtered interfaces such as the online opinion polling, 'online reception area,' or the sound-bite sized Twitter scroll" (Gorham 2014, 246). In a similar vein, Florian Toepfl $(2012,1454)$ argues that, when it concerns the leaders of Russia's federal subjects, "most Russian governors did not set up their blog primarily with the intention of gaining electoral support." Instead, blogging was predominantly "a symbolic action that showcased their allegiance and loyalty to the president, who was widely known for his Internet enthusiasm" (Toepfl 2012, 1454).

In his capacity as prime minister, following Vladimir Putin's return to the presidential office in 2012, Medvedev moved his most visible online presence to Twitter and Instagram, following the shifts in the platforms' popularity. Compared to his earlier presence on LiveJournal, the Instagram account is administered as a personal account, alternating between press photographs and pictures taken by Medvedev himself, accompanied with brief captions. Contrary to the LiveJournal blog, there is some interaction between the prime minister's account and other users on the platform, with Medvedev now and then commenting and responding. The increased personal dimension of Medvedev's social media presence may be explained by changing public relations (PR) 
needs - aimed to remedy the previous lack of connection with citizens and following the more general trend of increased personalization of politics. The fact that Instagram is predominantly image-based-Medvedev is known to have an interest in photography - and allows one to post, edit and comment quickly through the application on one's smartphone may also have been factors.

Yet, the decision to switch to Instagram also created vulnerabilities. Indeed, it was Medvedev's Instagram that provided opposition leader Alexei Navalny's Anti-Corruption Foundation with crucial visual evidence to tie together various publicly available sources of information indicating the prime minister's involvement in large-scale corruption (including hacked emails leaked by Russian hacker collective Šaltaj Boltaj [Humpty Dumpty], Global Positioning System [GPS] tracking of naval movements and various official registries). The results of the investigation were published in a video entitled "On vam ne Dimon" ("He is not Dimon to you") shared through FBK's YouTube channel and website. While this was not the first video FBK published that exposes corrupt practices by Russian state officials - indeed, there are many-the Dimon video gained particular traction online (by December 2019: 32.8 million views). More importantly, it served as the occasion for mass anti-corruption protests on March 26, 2017, that mobilized thousands of protesters across Russia $^{1}$; the largest demonstrations to take place since the protest movement of 2011-2012. FBK's investigations demonstrate how open source data-some of which became available as part of the implementation of open government ideas - can be effectively used to scrutinize and challenge government practices.

On the sub-federal level, Ramzan Kadyrov, the head of the Republic of Chechnya, is one of the Russian political actors who has most successfully used social media to increase his popularity, both in Chechnya and (far) beyond. His Instagram account, with posts that blended "discussion of politics with photos of himself hugging cats, posing in a knight's outfit, working out in a gym, and throwing snowballs with friends" (Rodina and Dligach 2019, 95) collected some three million followers, before the platform decided to shut down his account. Kadyrov's posts merged public, political and private spheres to the extent that "all of the personal topics contain elements of political framing, and most of the public/political topics include terminology that refers to personal topics such as friendship and family" (Rodina and Dligach 2019, 106). Kadyrov's success exemplifies how social media "can be used to normalize despotism, giving a modern-day dictator 'a human face"' (Rodina and Dligach $2019,96)$. The increasing use of social media in political communication is visibly changing the communication strategies used by the Russian Ministry of Foreign Affairs as well, whose official Twitter account incorporates vernacular language and actively partakes in online debates (Zvereva 2020). The Ministry's spokesperson, Maria Zakharova, in particular, has adopted a style of communication that blends formal and informal statements, expressed through multiple (and at times parallel) accounts on, for example, Facebook and Twitter.

Digitalization has also changed the rules of the game when it comes to political contestation by citizens. The rise of the Russian "blogosphere" and, 
subsequently, the popularity of bloggers, citizen journalists and vloggers on social media and YouTube, brought about novel opportunities for sharing political criticism with a wide audience, and for creating communities around a political cause (of which Navalny is but one example). Over time, the Russian government has responded to this perceived threat in multiple ways. Most notably, with the so-called "Bloggers' Law" (Federal Law No. 97-FZ) it introduced a special register for bloggers with a daily audience of $>3000$ visitors in 2014. For bloggers, some of whom published under a pseudonym, the registration involved, among other requirements, the disclosure of their real identities to the Russian authorities. The impact of the measure on the expression of political criticism online is difficult to ascertain, yet it is known that its introduction did not lead to any blogs being blocked or fines imposed (Soldatov 2019). Nonetheless, as Oleg Soldatov points out, "the mere existence of the public list of popular Internet personalities, administered by and conceived in the interests of a governmental body, should have led to a certain number of such personalities thinking twice before making public their criticism of the government" (Soldatov 2019, 70-71).

The law was repealed in 2017, which can be explained by a combination of factors: the ineffectiveness of the register and difficulties in enforcing the law (e.g. poor definition of who counts as a blogger, estimation of daily audience); a change of policy towards other control strategies (expanding restrictions on the publication of particular types of content); as well as the recognition that the practice of blogging was rapidly losing ground to other forms of online expression, most notably the shift to social media and video sharing platforms. Around the same time, the government attempted to co-opt some of these online "influencers." Popular vlogger Sasha Spilberg was invited to address the State Duma in May 2017, and soon after a special "bloggers council"-in full, Sovet po razvitiû informacionnogo obsestva $i$ sredstv massovoj informacii (Council on the Development of Information Society and Mass Media)—was convened on the initiative of Vladimir Vlasov, the youngest member of parliament. The council got off to a bad start since only a third of the invited bloggers took part, and the most popular Russian vloggers publicly distanced themselves from the initiative, including oppositional vloggers such as Kamikadzedead (Makutina 2017). The council has since convened incidentally, yet appears to be of limited influence and predominantly speaks out in support of governmental restrictions on online speech.

\subsection{Political Campaigning}

Political campaigns in Russia tend to be candidate-centered, rather than focusing on policy issues or political parties, a feature resulting from the constitutionally strong president and other characteristics of the electoral system (Ishiyama 2019). As an "electoral authoritarian regime" (Gel'man 2015), election outcomes in Russia are deemed important, even if the elections themselves are unfair. By extension, political campaigns are a significant feature of Russian 
politics. ${ }^{2}$ As is noted by Sergei Samoilenko and Elina Erzikova, "[t]he traditional boundaries between news and political advertising have eroded in Russia" and unfair practices, such as "[h]idden advertising, black PR and biased news reporting" have been a common feature since the 1990s $(2017,265)$. Television and print media have played an important role in political campaigning and media ownership is generally seen as an important factor in explaining election outcomes, most notably Boris Yeltsin's victory in the 1996 presidential elections. ${ }^{3}$

The parliamentary elections of 2011 were the first in which the Internet played a role of significance in how election campaigns were run, resulting from both the increase of Internet access and the expansion of online party presence in the years preceding it (Roberts 2015; Samoilenko and Erzikova 2017). While party websites appeared already at the time of the 1999 parliamentary elections, by 2011 political campaigning via social networking sites had become a common feature. Edinaâ Rossiâ (United Russia), as the "party of power," was particularly prolific and was active on multiple platforms in large measure because it had access to the resources needed to finance investing in the online dimension of its campaign. For example, the party's Twitter account (er_2011) "issued an average of over 360 tweets per day during the intensive campaign period-more in a single day than the LDPR [Liberal Democratic Party of Russia, led by conservative nationalist Vladimir Zhirinovsky, M.W.] and Yabloko [party of social-liberal orientation, M.W.] managed in the whole of the campaign, literally swamping the tweets from other parties," while amassing 600 videos on its YouTube channel by December 2011 (Roberts $2015,1235)$.

On the candidate level, however, a different picture emerges. Analyzing the online campaigns of 910 candidates representing the seven political parties that were successfully registered for the elections, Sean Roberts found that only 111 of them (12\%) maintained either a website, a Twitter account or a LiveJournal blog, while this percentage was markedly higher among United Russia candidates $(43 \%)$ (Roberts 2015, 1236, 1238). However, a significant number of these accounts were dormant during the campaign period, suggesting "that United Russia candidates were being forced to use social networks by the party leadership making them at best reluctant web users, at worst 'dissenters' by deliberately failing to maintain their accounts" (Roberts 2015, 1245). Notwithstanding United Russia's more extensive online activities, Roberts found "evidence of equalization [a relative leveling of the political playing field in favor of opposition parties, M.W.], as the online message of the remaining party candidates converged on an anti-United Russia theme" (Roberts 2015, 1229).

The availability of resources appears to be a key determinant in whether a party decides to invest in developing online campaigning strategies. In this respect, a clear difference has emerged between the campaigning style of United Russia, whose "campaigns have become increasingly professionalized and digitized, with expansive media campaigns funded by administrative 
resources" while its main competitor, the communist party KPRF (Kommunisticeskâa partiâ Rossijskoj Federacii, Communist Party of the Russian Federation), still "relies heavily on traditional methods of local party organization, voter mobilization (particularly older voters), newspaper advertisements, short television spots, public appearances by Zyuganov and other KPRF leaders, and campaign flyers and posters" (Ishiyama 2019). Of the remaining parties represented in parliament, the LDPR operates more similar to United Russia, but without the same access to large budgets, while the campaigning of Spravedlivấ Rossiâ (A Just Russia) is more alike to the KPRF (Ishiyama 2019).

The significance of the availability of digital technologies appears to have been the greatest for opposition groups who are not represented in the Russian parliament (sometimes referred to as the "non-systemic" opposition) and who lack access to traditional media. A closer look at two campaigns run by Alexei Navalny - for the 2013 Moscow mayoral elections and 2018 presidential elections-demonstrates this well. As is argued by Renira Gambarato and Sergei Medvedev (2015), Navalny's mayoral campaign (which build upon the 2011-2012 protest movement; see Lonkila et al. 2020) introduced a new form of political campaigning in Russia that was more grassroots (e.g. through online fundraising) and characterized by the use of transmedia strategies. ${ }^{4}$ Online tools were essential for spreading information regarding his political program - as the opposition candidate, Navalny was and continues to be barred access to mainstream media, in particular federal television-and to recruit campaign volunteers (Gambarato and Medvedev, 2015). These volunteers, in turn, campaigned both on- and offline, while social media played an important facilitating role in attracting people to these offline events. While Sergey Sobyanin won the elections in the first round by garnering some 51 percent of the votes, Navalny's 27 per cent showed the success of the campaigning strategies employed. Navalny's 2018 presidential campaign, which built upon the momentum generated following the anti-corruption protests discussed earlier, optimized many of these strategies, incorporating sophisticated big data analysis techniques. At the same time, it invested heavily in the creation of a network of local headquarters and volunteer groups. Navalny's campaign activities therefore show the continued mutual interdependence of online and offline campaigning, and the need to coordinate between and integrate both approaches. Contrary to the mayoral elections, the success of Navalny's presidential campaign cannot be substantiated by election results: in December 2017, the Central Election Commission of the Russian Federation decided Navalny was not eligible to run for president because of his previous conviction in a (much contested) fraud case. ${ }^{5}$

Notwithstanding the novel opportunities for political opposition, mobilization and campaigning provided by digital technologies, it remains difficult for those acting outside of the political establishment to be elected to a post of political importance or to otherwise effectuate significant political change. Gunitsky (2015) furthermore argues that the co-optation of social media by 
authoritarian regimes in fact serves as a way out of the limitations contained in the "dictator's dilemma" that was introduced above. Social media co-optation, he argues, can serve the resilience of authoritarian regimes by enabling, among other things, the introduction of alternative frames-for example, counter to those formulated by opposition groups- to shape public discourse online.

\subsection{Voting}

The digitalization of various aspects of the voting process was made possible by the adoption of the law "O gosudarstvennoj avtomatizirovannoj sisteme Rossijskoj Federacii "Vybory" (On the State Automated System of the Russian Federation [called] 'Elections', no. 20-FZ, 20 January 2003). "Electronic urns," that is, ballot boxes equipped with a special lid that scans the ballot paper when it is entered, counts the votes that have been cast and prints out the results, were first introduced in 2004 (kompleks obrabotki izbiratel'nyh bûlletenej, referred to in Russian by the abbreviation KOIB). The systems were introduced with the stated aim to prevent miscalculations and speed up the voting process, while also preventing ballot box stuffing since only one paper can be passed through the scanner at a time. E-voting machines (kompleks dlâ

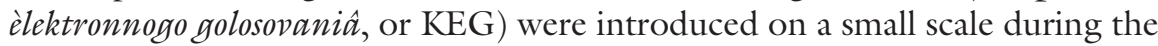
2007 elections, after having been successfully tested in 2006 in an election in Veliky Novgorod. By 2018, most Russian federal districts used KOIB and/or KEG systems, albeit on greatly diverging scales; in total $11.1 \%$ of votes were counted automatically (RIA 2018).

Russia only recently trialed remote electronic voting, and on a modest scale: during the 2019 Moscow City Duma elections the voters of three electoral districts were given the option to vote online. The experiment did not run flawlessly. Already during the preparatory phase, the security of the system was questioned; moreover, the fact that it was run by the city of Moscow and voters' identity and right to vote were verified by the Moscow Mayor's portal, rather than the Multifunctional Centers for Governmental and Municipal Services normally endowed with this task, was criticized (Vasil'chuk 2019). In May 2019, the Communist Party filed a case with the Supreme Court in an attempt to prohibit the use of online voting in the Moscow elections, citing concerns about the violation of voting secrecy and the risk of manipulation and coercion of voters (Garmonenko 2019); the Supreme Court found the experiment not to be in violation of the Constitution. On the day of voting, September 8,2019 , the online voting system experienced multiple interruptions, which caused the service to be offline for periods of up to one hour (Kommersant 2019).

In the three districts where it was introduced, online voting appears to have worked in favor of pro-regime candidates who received a higher percentage of the online votes as compared to the paper votes, while the opposite was the case for opposition candidates (Uspenskiy 2019). In one of the districts that participated in the trial, the independent candidate would have won on the basis of paper votes only, yet lost the election by a mere 84 votes with the 
addition of votes cast online (Vasil'chuk 2019). The explanation for the fact that pro-regime candidates fared comparatively well among those voters who voted online has yet to be determined. One thinkable scenario is that the introduction of online voting, and thereby the removal of the controlled conditions of the polling station that aim to ensure voter secrecy and freedom of choice, makes, for example, civil servants even more vulnerable to coercion. While it commonly understood state employees are placed under pressure to vote (to increase voter turnout) and support a given candidate, online voting creates the opportunity for superiors to directly supervise how their employees vote (e.g. by having them vote at the workplace). Whether and to what extent this is indeed the case, and to what extent other factors may be able to explain this difference, requires further investigation. Moreover, to be able to draw definitive conclusions on how the introduction of online voting may affect political outcomes, the empirical base needs to be extended as further trials with online voting are conducted.

Apart from the automation of voting and the gradual introduction of voting machines, the conditions under which Russians vote has changed through the placement of webcams. In response to (proven) accusations of electoral fraud committed during the December 2011 parliamentary elections, that gave cause to a series of mass protests, the government installed webcams at nearly all polling stations for the 2012 presidential elections to allow for real-time monitoring via a special website (webvybory2012.ru). In total, 91,000 of the 95,000 polling stations had a total of 180,000 cameras installed; of these, 80,000 were streamed online and with sound (Asmolov 2014). Webcams had been in use earlier, but only on a small scale. According to Gregory Asmolov, the actual impact of this massive infrastructural investment on increasing the transparency and, in particular, the accountability of the voting process was limited by the lack of an integrated mechanism for reporting fraudulent behavior, the impossibility of recording live-streamed footage (requiring one to file an official request to gain access to centrally stored footage from the webcams) and the ill-defined legal status of the recordings. As a result, no "criminal conviction of electoral fraud or revision of election results" were made on the basis of the videos (Asmolov 2014). Moreover, for volunteer monitors, the sheer number of available live streams made it difficult to monitor effectively. Beyond polling stations, webcams had earlier been used on smaller scale to monitor the progress on national projects in 2007, and in 2010 to monitor the reconstruction process following the wildfires. According to Asmolov, however, these initiatives symbolized rather than truly increased government transparency and accountability, as was their supposed aim (Asmolov 2014).

The 2012 presidential elections also saw the first use of a specially developed app for election observers called Web-nabludatel' (web-observer) (Ermoshina 2016). The app, developed with the involvement of NGO (non-governmental organization) Golos (Voice), provided observers with guidance on how to conduct their activities, as well as giving them the ability to report any violations. The app was connected to a website hosting a collaborative map and statistics, 
which provided novel insight into the extent and distribution of suspect and fraudulent behaviors. The aggregation of information, as well as the support the app provided for individuals volunteering to act as election observers, are important for consolidating proper election observation practices and enabling follow-up political actions.

In addition to the government, opposition forces have also turned to online voting as a means for creating legitimacy. As the 2011-2012 protest movement sought to transition from street protests into a sustained political opposition movement, an online vote was organized to elect the Koordinacionnyj sovet rossijskoj oppozicii (Coordination Council of the Opposition) (Toepfl 2017). It was believed that this strategy would help remedy the lack of internal coherence and coordination (and as a result, credibility and legitimacy) that has undermined the success of earlier protests and opposition movements. The council was short lived, however, as the legitimacy provided by the voting process proved insufficient to remedy the fault lines within the opposition it sought to unite and was dissolved in 2013.

\subsection{Civic Tech and Civic Engagement}

In addition to the changes described above, digitalization has enabled new forms of political participation, among others, through the introduction of online consultation platforms. Florian Toepfl $(2018,960)$ proposes to categorize such digital participatory tools into four groups: tools that allow citizens to monitor policy implementation; tools enabling the public discussion of policies, measures or draft laws; tools that collect citizen preferences; and, forms of Internet voting outside of the electoral system. Above, we have already come across examples of the first - webcams used to monitor the progress of national projects - and second groups-the regulation.gov.ru portal for the public discussion of draft laws. The third group Toepfl identifies comprises tools that collect citizen preferences and thereby allow the government to "gauge the intensity of support for, or resistance to, planned measures or policy changes" (Toepfl 2018, 960). For example, the Rossijskâे obsestvennaâ iniciativa (Russian public initiative) portal (roi.ru) that was introduced in 2013 allows citizens to submit an initiative to the government and cast their vote for proposals posted by others. If the initiative receives a sufficient number of votes, it will be discussed by expert working groups of the relevant federal, regional or municipal authorities (at least 100,000 signatures for proposals at the federal level or in regions with a population of over two million; or over five percent of the registered population for proposals aimed at regional and municipal governments). According to data published by the portal on the occasion of its sixth anniversary in April 2019, a total of 50,531 initiatives were submitted since its introduction, that received 17,970,021 votes in favor and 2,615,479

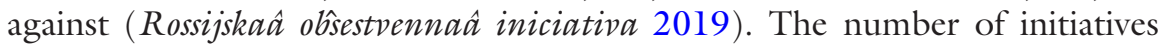
that led to government action, however, is limited: 33 initiatives resulted in a 
decision, while 19 proposals succeeded in gathering over 100,000 votes in support.

The final group outlined by Toepfl concerns forms of Internet voting outside of the electoral system. The Active Citizen Platform of the city of Moscow, for example, allows inhabitants to decide on questions put before them by the city council; from naming metro stations and trains to school vacation dates. Citizen budgets - where online platforms are used as a tool for increasing budgetary transparency or to facilitate participatory budgeting, in which citizens have a say in the spending of state resources-are another example of this category. The city of Yakutsk, for instance, provides extensive insight into its sources of income and spending, while providing core information concerning the budgetary process (openbudget.yakadm.ru). While, in the case of such citizen budget portals, opportunities for citizen participation are limited, participatory budgeting initiatives are more ambitious. In 2016 the city of St. Petersburg, for example, launched the Tvoj Bûdžet project (Your Budget, tvoybudget.spb.ru) in collaboration with the European University of St. Petersburg. Through its online portal, citizens can propose how resources should be spent in their neighborhood. Based on the total number of submitted proposals, a small number of districts (both inner city and suburbs) is then selected and allocated an earmarked budget of up to 15 million rubles for the realization of between one and three initiatives. In a special meeting, a budget committee is formed from among the initiators (by draw). The members of the committee then take part in a series of lectures to learn about, for example, urban planning and budgeting, in order to further develop their ideas. The final plans need to secure support from the district administration and be voted upon by the members of the budgeting committee in order to receive funding (Antonov 2018). One of the most visible citizen initiatives realized through Your Budget is a stretch of cycling lanes along one of the city's central canals.

Analyzing another example of the last category - the online voting to elect members for the President's Council on the Development of Civil Society and Human Rights in 2012-Toepfl argues such tools serve to strengthen, rather than weaken authoritarian rule, while simultaneously "convey[ing] to the mass public the image of transparent, accountable, and responsive government" (Toepfl 2018, 958). Studies of the use of online participatory tools by autocratic regimes elsewhere indicate that we, indeed, should not expect too much of a democratizing effect from civic tech. In China, for example, the authorities do appear to incorporate citizen input received through online consultation platforms, where a higher number of comments demanding a revision is found to increase the likelihood of the policy being revised (Kornreich 2019). In a similar vein, Jiang et al. $(2019,532)$ find that "cities that receive a larger number of online petitions in a year tend to devote significantly higher proportions of government reports in the following year to a topic on social welfare," which reflects the majority of concerns expressed in the petitions. Yet, this type of citizen influence remains limited, at best, and does not necessarily translate into sustained political change or the upscaling of political participation to other/ 
higher levels of politics. As Yoel Kornreich explains, a certain degree of "authoritarian responsiveness" is to be expected since "[f]ailure to address citizen feedback will undermine the regime's credibility," while simultaneously undermining "citizens' motivation to participate in consultation, thus depriving the authorities of an important information gathering channel" (Kornreich 2019, 549). Since legitimacy and information gathering are the main incentives for implementing civic tech, minimal functionality and effectiveness are insufficient indicators of democratization.

Whereas Toepfl's categorization captures the governmental side of civic tech, digitalization has also enabled novel forms of civic engagement. On the local and regional levels, in particular, manifold civic initiatives (portals) have been successfully launched aimed at e-participation (e.g., urban improvement), at times acting in direct competition with government-initiated e-participation portals. Analyzing such "civic apps" in Russia, Ksenia Ermoshina argues that, while "a civic application can become a means to overcome the existing dysfunctions in communication between citizens and official institutions," they are still best suited to solving "problems that can be easily classified and are regulated by a definite legal basis" (Ermoshina 2016, 128, 137). Successful examples include RosYama (Russian pit), an app developed by Alexei Navalny's Anti-Corruption Foundation to map and draw attention to potholes in Russian roads or RosZKH (Russian housing and communal services) that "help[ed] individuals write petitions to the Housing Inspection Committees responsible for oversight of their particular block of flats" (Ermoshina 2014).

The two types - civic tech and civic apps-are not always perfectly separated, nor do civic apps always empower citizens vis-à-vis the state. In his study of emergency response volunteering platforms, Gregory Asmolov demonstrates the different shapes the power relations between authorities and/or platform administrators and volunteers can take. Rather than enabling more horizontal, peer-to-peer forms of (self-)organization, the way platforms for citizen engagement operate risk taking on the characteristics of "vertical crowdsourcing," in which,

the structure of activity is defined by the institutional actor, with no space for the influence of agency on the system's structure. In this case the purpose of the system, the boundaries, the rules, the right to participate in the community, and the division of labor are dictated by the agent who created the platform. In many cases the purpose of this type of activity system is primarily to control the activity of the crowd and to neutralize the potential for independent forms of activity. (Asmolov 2015, 311)

Instead of empowering citizens in their capacity to address societal issues, vertical crowdsourcing of resources impedes action independent of state or state-affiliated structures, who may view such citizen initiatives as threatening their position. 


\subsection{Conclusion}

In this chapter, I have examined the impact of digitalization on Russian politics, covering the spheres of political communication, campaigning, voting, civic tech and civic engagement. From blogging politicians to online political campaigning, open government data and participatory budgeting-digital technologies evidently are shaping how politics is conducted in Russia and who can participate in and influence political decision-making. Some of the changes and initiatives I have examined are best categorized as digital replications of existing political practices or have only limited impact on political practices. The introduction of voting computers, for example, is a slow process that, thus far, does not appear to affect election outcomes. Most online participatory tools lack bite. Yet, it appears that several spheres of Russian politics have indeed been transformed as a result of digitalization. This concerns, in particular, the novel opportunities that have emerged for conducting and organizing political opposition, including political campaigning by opposition candidates, and civic engagement. At the same time, these transformations do not necessarily result in the strengthening of the democratic degree of political practices. Rather, the cases and studies reviewed in this chapter support the claim that in many cases digital tools for political participation serve to strengthen, rather than weaken, state control.

\section{Notes}

1. According to police estimates, some 7000 persons took part in the Moscow protest and 5000 in St. Petersburg. Several hundreds of protesters were arrested, including Navalny.

2. For an overview of campaign characteristics from 1993-2016, see Ishiyama (2019).

3 . On election campaigning and changes in political advertisement, including the use of compromising materials (kompromat) in the period 1993-2014, see Samoilenko and Erzikova (2017).

4. Gambarato and Medvedev $(2015,176)$ identify a total of 32 different elements to the campaign, ranging from political advertisements, banners and stickers to distributing campaign materials on public transport and an online couch surfing service for volunteers.

5. Unlike Navalny, former socialite Ksenia Sobchak did succeed in being registered as a candidate and ran an oppositional campaign with the motto "Sobchak against all." Boasting a massive following on Instagram, social media were at the center of her campaign. Contrary to Navalny, though, Sobchak did receive coverage on federal television and participated in the televised debates of presidential candidates (president Putin was conspicuous by his absence). 


\section{REFERENCES}

Antonov, E. 2018. Lûboj peterburžec možet postroit' velodorožki ili otkryt' punkt obogreva za sčet gorodskogo bûdžeta [Any Petersburger Can Build Bike Paths or Open a Heating Point at the Expense of the City Budget]. Bumaga, February 27. https://paperpaper.ru/tvoi-budzhet/.

Asmolov, Gregory. 2014. The Kremlin's Cameras and Virtual Potemkin Villages: ICT and the Construction of Statehood. In Bits and Atoms. Information and Communication Technology in Areas of Limited Statehood, ed. Steven Livingston and G. Walter-Drop, 30-46. New York: Oxford University Press.

2015. Vertical Crowdsourcing in Russia: Balancing Governance of Crowds and State-Citizen Partnership in Emergency Situations. Policy and Internet 7 (3): 292-318.

Castells, Manuel. 2012. Networks of Outrage and Hope: Social Movements in the Internet Age. Cambridge and Malden: Polity Press.

Coleman, S., and D. Freelon. 2015. Introduction: Conceptualizing Digital Politics. In Handbook of Digital Politics, ed. Stephen Coleman and Deen Freelon, 1-13. Cheltenham and Northampton: Edward Elgar Publishing Limited.

Deibert, Ronald, John Palfrey, Rafal Rohozinski, and Jonathan Zittrain. 2010. Access Controlled. The Shaping of Power, Rights, and Rule in Cyberspace. Cambridge, MA: MIT Press.

Diamond, L. 2010. Liberation Technology. Journal of Democracy 21 (3): 69-83.

Ermoshina, Ksenia. 2014. Democracy as Pothole Repair: Civic Applications and Cyberempowerment in Russia. Cyberpsychology: Journal of Psychosocial Research on Cyberspace 8 (3). https://doi.org/10.5817/CP2014-3-4.

- 2016. Is There an App for Everything? Potentials and Limits of Civic Hacking. Observatorio Journal 10: 116-140. https://doi.org/10.15847/ obsOBS0020161088.

Gambarato, Renira, and Sergei Medvedev. 2015. Grassroots Political Campaign in Russia: Alexey Navalny and Transmedia Strategies for Democratic Development. In Promoting Social Change and Democracry through Information Technology, ed. Vikas Kumar and Jakob Svensson, 165-192. Hershey: IGI Global.

Garmonenko, Daria. 2019. KPRF trebuet priznat' èlektronnoe golosovanie ne sootvetstvuûsisim Konstitucii [KPRF Demands to Recognize Electronic Voting as Not Complying with the Constitution]. Nezavisimaâ gazeta, May 13. http://www. ng.ru/politics/2019-05-13/3_7571_kprf.html.

Gel'man, V. 2015. Authoritarian Russia: Analyzing Post-Soviet Regime Changes. Pittsburgh: Pittsburgh University Press.

Gorham, Michael. 2014. Politicians Online: Prospects and Perils of 'Direct Internet Democracy'. In Digital Russia, ed. Michael S. Gorham, Ingunn Lunde, and Martin Paulsen, 233-250. Abingdon and New York: Routledge.

Gunitsky, Seva. 2015. Corrupting the Cyber-Commons: Social Media as a Tool of Autocratic Stability. Perspectives on Politics 13 (1): 42-54.

Ishiyama, John. 2019. Russia. In Thirty Years of Political Campaigning in Central and Eastern Europe, ed. Otto Eibl and Milos Gregor, 391-408. Palgrave Macmillan.

Jiang, Junyan, Tianguang Meng, and Qing Zhang. 2019. From Internet to Social Safety Net: The Policy Consequences of Online Participation in China. Governance 32: 531-546. 
Kommersant. 2019. Onlajn-golosovanie v Moskve dvaždy priostanavlivali iz-za sboâ [Online Voting in Moscow Twice Suspended Due to a Failure]. Kommersant, September 8. https://www.kommersant.ru/doc/4086901.

Kornia, Anastasia. 2017. Verhovnyj sud razrešil Rosreestru zasekretit' svedeniâ o vladel'cah nedvižimosti [The Supreme Court Allowed Rosreestr to Classify Information about Property Owners]. Vedomosti, October 18. https://www.vedomosti.ru/realty/articles/2017/10/19/738417-razreshil-zasekretit-svedeniyavladeltsah-nedvizhimosti.

Kornreich, Yoel. 2019. Authoritarian Responsiveness: Online Consultation with 'Issue Publics' in China. Governance 32: 547-564.

Lonkila, Markku, Larisa Shpakovskaya, and Philip Torchinsky. 2020. The Occupation of Runet? The Tightening State Regulation of the Russian-Language Section of the Internet. In Freedom of Expression in Russia's New Mediasphere, ed. Mariëlle Wijermars and Katja Lehtisaari, 17-38. Abingdon and New York: Routledge.

MacKinnon, R. 2011. Liberation Technology: China's 'Networked Authoritarianism'. Journal of Democracy 22 (2): 32-46.

Makutina, Mariia. 2017. Sovet bez blogerov [Council Without Bloggers]. RBC, June 19. https://www.rbc.ru/newspaper/2017/06/20/5947e6469a794764344b7a27.

Peterson, D. J. 2005. Russia and the Information Revolution. Santa Monica, CA: RAND Corporation.

Podshibyakin, A. 2010. Po živomu. 1999-2009: LiveJournal v Rossii [Live Cut. 1999-2009: LiveJournal in Russia]. Moscow: KoLibri.

RIA Novosti. 2018. Demokratiâ v bezopasnosti [Democracy Is Safe]. February 21. https://ria.ru/20180221/1514773317.html.

Roberts, Sean P. 2015. Online Campaigning in Russia: Evidence from the 2011 State Duma Election. Europe-Asia Studies 67 (8): 1228-1250.

Rodina, E., and D. Dligach. 2019. Dictator's Instagram: Personal and Political Narratives in a Chechen Leader's Social Network. Caucasus Survey 7 (2): 95-109.

Rossijskaâ ob̂sestvennaâ iniciativa [Russian Public Initiative]. 2019. Portalu Rossijskaâ obŝestvennaâ iniciativa ispolnâetsâ 6 let! [Russian Public Initiative Portal is 6 Years Old!], April 2. https://www.roi.ru/news/79/.

Samoilenko, Sergei A., and Elina Erzikova. 2017. Media, Political Advertising and Election Campaigning in Russia. In Routledge Handbook of Political Advertising, ed. Christina Holz-Bacha and Marion R. Just, 253-268. New York: Routledge.

Smyth, Regina. 2016. Studying Russia's Authoritarian Turn. Russian Politics 1 (4): 337-346.

Soldatov, Oleg. 2019. Half-hearted Inception, Miserable Existence, and the Untimely Death of the Bloggers' Register in Russia. Israel Law Review 52 (1): 61-75.

Toepfl, Florian. 2012. Blogging for the Sake of the President: The Online Diaries of Russian Governors. Europe-Asia Studies 64 (8): 1435-1459.

2017. From Connective to Collective Action: Internet Elections as a Digital Tool to Centralize and Formalize Protest in Russia. Information, Communication o Society 21 (4): 531-547.

2018. Innovative Consultative Authoritarianism: Internet Votes as a Novel Tool to Stabilize Non-democratic Rule in Russia. New Media \& Society 20 (3): 956-972.

Uspenskiy, Alexander. 2019. Èlektronnoe golosovanie v Moskve vyigrali kandidaty ot vlasti. V oflajn-golosovanii u nih net takogo perevesa [Candidates from the 
Authorities Won the Electronic Voting in Moscow. They Have No Such Advantage in Offline Voting]. TJ, September 9. https://tjournal.ru/ analysis/115536-elektronnoe-golosovanie-v-moskve-vyigrali-kandidaty-ot-vlasti-voflayn-golosovanii-u-nih-net-takogo-perevesa.

Vaccari, Cristian. 2013. Digital Politics in Western Democracies: A Comparative Study. Baltimore: Johns Hopkins University Press.

Vasil'chuk, Tatjana. 2019. 'Miški' na servere. Kak onlajn-golosovanie privelo v Mosgordumu kandidatov, podderžannyh 'Edinoj Rossiej' ['Bears' on the Server. How Online Voting Brought Candidates Supported by 'United Russia' to the Moscow City Duma]. Novaya gazeta, September 12. https://novayagazeta.ru/ articles/2019/09/12/81950-mishki-na-servere.

Yagodin, Dmitry. 2012. Blog Medvedev: Aiming for Public Consent. Europe-Asia Studies 64 (8): 1415-1434.

Zvereva, Vera. 2020. State Propaganda and Popular Culture in the Russian-Speaking Internet. In Freedom of Expression in Russia's New Mediasphere, ed. Mariëlle Wijermars and Katja Lehtisaari, 225-247. Abingdon and New York: Routledge.

Open Access This chapter is licensed under the terms of the Creative Commons Attribution 4.0 International License (http://creativecommons.org/licenses/ by/4.0/), which permits use, sharing, adaptation, distribution and reproduction in any medium or format, as long as you give appropriate credit to the original author(s) and the source, provide a link to the Creative Commons licence and indicate if changes were made.

The images or other third party material in this chapter are included in the chapter's Creative Commons licence, unless indicated otherwise in a credit line to the material. If material is not included in the chapter's Creative Commons licence and your intended use is not permitted by statutory regulation or exceeds the permitted use, you will need to obtain permission directly from the copyright holder. 